Original Research Article

\title{
Analgesic activity of aqueous extract of Amorphophallus paeoniifolius in Swiss albino mice
}

\author{
Hemalatha A., Sathiya Vinotha A. T.*
}

Department of Pharmacology, Karpagam Faculty of Medical Sciences \& Research,

Coimbatore, Tamil Nadu, India

Received: 01 April 2019

Revised: 26 April 2019

Accepted: 03 May 2019

\section{*Correspondence to:}

Dr. Sathiya Vinotha A. T., Email: drs.vinotha@gmail.com

Copyright: (C) the author(s), publisher and licensee Medip Academy. This is an openaccess article distributed under the terms of the Creative Commons Attribution NonCommercial License, which permits unrestricted noncommercial use, distribution, and reproduction in any medium, provided the original work is properly cited.

\begin{abstract}
Background: Pain is defined as an unpleasant feeling caused by intense or damaging stimuli. Amorphophallus paeoniifolius known as "Elephant foot yam" is a highly potential tropical tuber crop of Araceae family. The tubers are used as antihaemorrhoidal, haemostatic, expectorant, appetizer, anthelmintic, aphrodisiac and rejuvenating agent. Diclofenac, a COX inhibitor is used as analgesic widely. Analgesic activity of alcoholic extract of Amorphophallus paeoniifolius has been proved in previous animal studies.

Methods: Swiss Albino mice of either sex (20-30g) were procured from the central animal house of KFMS\&R, Coimbatore. Animals were maintained under controlled temperature and light conditions with food and water ad libitum. Mice were kept in the department to get acclimatized. 24 mice were divided into 4 groups $(n=6)$. Drugs were given orally after 12 hours of fasting. Group I was the control received normal saline, Group II received standard-diclofenac $(25 \mathrm{mg} / \mathrm{kg})$. Group III and Group IV received aqueous extract of Amorphophallus paeoniifolius $200 \mathrm{mg} / \mathrm{kg}$ and $400 \mathrm{mg} / \mathrm{kg}$ respectively.

Results: The latency period of Group IV (aqueous extract of Amorphophallus paeoniifolius $400 \mathrm{mg} / \mathrm{kg}$ ) was significant $(\mathrm{p}<0.01)$ compared to Group I (controls) and Group II (standard) was significant $(\mathrm{p}<0.001)$ when compared to Group IV (aqueous extract of Amorphophallus paeoniifolius $400 \mathrm{mg} / \mathrm{kg}$ ) by hot plate method. In acetic acid induced writhing when compared to control, the percentage inhibition of aqueous extract of Amorphophallus paeoniifolius was $43.65 \%$ at $200 \mathrm{mg} / \mathrm{kg}, 46.09 \%$ at $400 \mathrm{mg} / \mathrm{kg}$ and that of the standard was $54.39 \%$.

Conclusions: It was concluded that aqueous extract of Amorphophallus paeoniifolius has analgesic activity due to peripheral and central inhibition of prostaglandins synthesis. The extract may have phytoconstituents which inhibit COX enzyme peripherally or act on central opioid receptors( $\mu$ receptors) for producing analgesia. It can be used as an add-on drug there by reducing side effects by conventional analgesics.
\end{abstract}

Keywords: Analgesia, Acetic acid, Amorphophallus paeoniifolius, Diclofenac, Hot plate

\section{INTRODUCTION}

Pain is a warning signal protective in nature, an unpleasant sensory and emotional experience associated with actual and potential tissue damage. Drugs that selectively relieves pain by acting in the CNS or on peripheral pain mechanisms, without significantly altering consciousness are called analgesics. Pharmacologically analgesics are divided into two groups, opioid analgesic and non opioid analgesics. ${ }^{1}$ Drugs which relieves pain due to inflammation are called NSAIDS or non steroidal antiinflammatory drugs or Non opioid analgesics. These drugs act by decrease the production of prostaglandins which stimulates the pain receptors to inflammatory mediators. ${ }^{2}$ Now a days there is increased use of herbs as medicines worldwide for various conditions. This leads to look for therapeutic lead compounds from herbs which can be utilized for development of new drug. More than $50 \%$ of 
the newer drugs are of natural origin, which was developed by pharmaceutical companies. Epidemiological data suggests that dietary factors play an important role in the treatment of certain chronic diseases including cancer, diabetes, hypertension. In recent years the popularity of dietary factors and traditional plant therapies are used commonly in India. ${ }^{3}$

Amorphophallus paeoniifolius is basically a crop of south East Asian origin. It is also called as elephant foot yam. In India, its synonyms are "Suran" or "Jimmikand". It is widely distributed in wild form in Indonesia Philippines, Malaysia, and other South East Asian countries. ${ }^{4,5}$ It is widely used in many Ayurvedic preparations. This tuber is consumed by many people as a food. It has antiinflammatory, expectorant, anti-haemorrhoidal, appetizer, carminative, aphrodisiac, anthelmintic properties. It causes irritation in the mouth and throat because of its acidic nature due to excessive amount of calcium oxalate. It is reported to have CNS depressant, cytotoxic activity and antiprotease activity. In the world of pharmaceuticals now a days herbal drugs occupy a special place. Due to growing interest in natural herbs and Side-effects of conventional medicines, there is increased interest in medicinal plants. Herbal remedies have been developed through knowledge of herbs, which is a hope for several patients. ${ }^{6,7}$

The pharmacological properties of this plant have not been studied extensively so far. Therefore, the aim of our present study was to determine the detailed in-vivo analgesic activity of aqueous extract of Amorphophallus paeoniifolius in healthy swiss albino mice.

\section{METHODS}

\section{Plant and Preparation of the extract}

Amorphophallus paeoniifolius (Araceae) tuber was purchased from local market. The tuber of the plant was dried under shade and made to a fine powder and was extracted with water by using soxhlet extractor.

\section{Study population}

Male Swiss Albino mice (20-25g) were obtained from animal house of Karpagam faculty of medical sciences and research. The animals were housed under standard environmental condition (12 hrs light and 12 hrs dark cycle), fed with standard diet and water ad libitum. The experiments were performed with subject to minimum pain to the experimenting animals. Ethical approval was obtained from Animal Ethics Committee of Karpagam faculty of medical sciences and research. Study carried out for 3 months from September 2016-November 2016.

\section{Inclusion criteria}

There were 48 Male Swiss Albino mice (20-25g) obtained from animal house of Karpagam faculty of medical sciences and research and included in the study.

\section{Exclusion criteria}

Female mice, male mice with weight less than 20 and more than $25 \mathrm{~kg}$, mice with any other illness were excluded from the study.

\section{Chemicals}

Diclofenac (ACME Laboratories Ltd)-standard drug and $0.6 \%$ acetic acid, normal saline were used. ${ }^{8}$

\section{Acetic acid induced writhing test}

The 24 Swiss albino mice were taken for this study. The mice were divided into 4 groups of 6 animals in each. Group I was used as control receiving $0.5 \mathrm{ml}$ normal saline. Group II was given standard drug diclofenac $25 \mathrm{mg} / \mathrm{kg}$. Group III, IV received aqueous extract of Amorphophallus paeoniifolius in doses of 200 and $400 \mathrm{mg} / \mathrm{kg}$ respectively. Mice were intragastrically administered with test and control drugs $30 \mathrm{~min}$ before intraperitoneal injection of acetic acid $(0.6 \%)$. Then mice were placed in separate bell shaped transparent glass jars and numbers of abdominal constrictions (writhes) were counted over a period of 10 minutes commencing 10 min after injection of acetic acid. The difference in number of writhes in test group was compared with standard treated and control treated groups. ${ }^{9}$ The percentage increase/decrease in number of writhing (as index of analgesia) was calculated. The Percentage Inhibition was calculated by formula:

$\%$ Inhibition $=[(\mathrm{Wc}-\mathrm{Wt}) \times 100] / \mathrm{Wc}$

Where, $\mathrm{Wc}=$ No. of writhes in control group, $\mathrm{Wt}=\mathrm{No}$ of writhes in test group.

\section{Eddy's hot plate method}

The 24 Swiss albino mice weighing 20-30g were used. Mice were intragastrically administered with test and control drugs. $1 \mathrm{hr}$ after the ingestion of drugs mice were placed on the hot plate, which consists of electrically heated surface. Temperature of the hot plate was maintained at $55^{\circ} \mathrm{C}$.

Responses such as jumping, withdrawal of the paws and licking of the paws were observed. The time period (latency period) when animals were placed and until responses occur was recorded by the stopwatch. The latency period was recorded after 0, 60, 90 and $120 \mathrm{~min}$. These values were compared with the standard drug diclofenac and control normal saline. This model evaluates the central pain. ${ }^{10}$

\section{Statistical analysis}

Data obtained from the experiment was expressed as Mean \pm SEM. Difference between the control and the treatments in these experiments were tested for significance using one way analysis of variance 
(ANOVA). IBM SPSS statistics @ IBM Corporation 2012 software was used for statistical analysis purpose. Values of $\mathrm{P}<0.05$ were considered statistically significant.

\section{RESULTS}

\section{Eddy's hot plate method}

The standard drug diclofenac sodium showed significant increase in analgesic activity when compared with the control group of animals. Thus, the latency period of aqueous extract of Amorphophallus paeoniifolius was significantly $(\mathrm{P}<0.01)$ good when compared to control at time period 60-120 min, whereas the latency period of the standard was more significant $(\mathrm{P}<0.001)$ when compared to aqueous extract of Amorphophallus paeoniifolius at alltime intervals of experimentation (Table 1).

Table 1: Analgesic activity by hot plate method in mice.

\begin{tabular}{|lllll|}
\hline Groups & \multicolumn{4}{c}{ Reaction time in seconds } \\
& $\mathbf{0 m i n}$ & $\mathbf{6 0}$ min & $\mathbf{9 0} \mathbf{~ m i n}$ & $\mathbf{1 2 0} \mathbf{~ m i n}$ \\
\hline $\begin{array}{l}\text { Group I } \\
\text { (Control) }\end{array}$ & $24.5 \pm 1.9$ & $24.9 \pm 0.03$ & $25.0 \pm 1.4$ & $25.2 \pm 0.05$ \\
\hline $\begin{array}{l}\text { Group II } \\
\text { (Standard) }\end{array}$ & $55.8 \pm 3.5$ & $56.5 \pm 2.3$ & $58.4 \pm 3.3$ & $60.5 \pm 4.4^{* * *}$ \\
\hline Group III & $33.5 \pm 3.8$ & $40.5 \pm 0.4$ & $42.3 \pm 0.2$ & $43.4 \pm 0.8^{\text {a** }}$ \\
\hline $\begin{array}{l}\text { Group } \\
\text { IV }\end{array}$ & $40.5 \pm 1.9$ & $45.6 \pm 0.6$ & $46.7 \pm 0.5$ & $47.07 \pm 0.6^{* * *}$ \\
\hline
\end{tabular}

Each value is the mean \pm SEM for 6 mice, $* \mathrm{P}<0.05$; $* * \mathrm{P}<0.01$; $* * * \mathrm{P}<0.001$ compared with control. Data were analyzed by using One-way ANOVA

\section{Acetic acid induced writhing test}

Aqueous extract of Amorphophallus paeoniifolius which was given orally $30 \mathrm{~min}$ before intraperitoneal injection of acetic acid significantly reduced the number of writhes. Significant inhibition of the writhing response was observed after the administration of aqueous extract of Amorphophallus paeoniifolius $400 \mathrm{mg} / \mathrm{kg}$ when compared to normal saline control group.

Table 2: Analgesic activity by acetic acid induced writhing in mice.

\begin{tabular}{|ll|l|}
\hline Groups & No. of writhes & $\%$ inhibition \\
\hline Group I (Control) & $41.1 \pm 1.24$ & - \\
\hline Group II (Standard) & $18.8 \pm 1.8^{* * *}$ & $54.39 \%$ \\
\hline Group III & $23.2 \pm 2.5^{* *}$ & $43.65 \%$ \\
\hline Group IV & $22.2 \pm 1.4^{* *}$ & $46.09 \%$ \\
\hline
\end{tabular}

Each value is the mean \pm SEM for 6 mice, $* \mathrm{P}<0.05 ; * * \mathrm{P}<0.01$; $* * * \mathrm{P}<0.001$ compared with control. Data were analyzed by using One-way ANOVA

The number of writhes of aqueous extract of Amorphophallus paeoniifolius was less when compared to control whereas the number of writhes of standard drug (Diclofenac) were less when compared to aqueous extract of Amorphophallus paeoniifolius and normal saline. When compared to control, the percentage inhibition of aqueous extract of Amorphophallus paeoniifolius was $43.65 \%$ at $200 \mathrm{mg} / \mathrm{kg}, 46.09 \%$ at $400 \mathrm{mg} / \mathrm{kg}$ and that of the standard was $54.39 \%$ (Table 2).

\section{DISCUSSION}

The present study was conducted to evaluate the analgesic activity of aqueous extract of Amorphophallus paeoniifolius and to explore the mechanism of action. Pain usually arises from three major classes of initiating conditions: (a) acute high intensity stimuli; (b) tissue injury and inflammation; and (c) injury to a specific peripheral nerve (mononeuropathy, e.g. crush, section) or to all peripheral sensory nerves (polyneuropathy, e.g. diabetes, chemotherapy, or an immune-mediated reaction). Excitation of nociceptors or their afferent free nerve endings leads to pain. Pain is mediated through A $\delta$ fibers and $\mathrm{C}$ fibers, respectively called as fast and slow pain. Nociception is the mechanism; whereby noxious peripheral stimuli are transmitted to the central nervous system. ${ }^{11}$ Nociceptive fibers terminate in the superficial layers of the dorsal horn, forming synaptic connections with transmission neurons running to the thalamus. Neurogenic inflammation occurs due to release of transmitters glutamate, substance $P$ from the nociceptors. ${ }^{12}$ There has been a focus on developing novel drugs in the pain management. There are several groups of drugs have been recognised in pain therapeutics. These groups of drugs have varying efficacy in the different types of pain. Many adverse events have been reported for these drugs which limits their utility. Nonsteroidal anti-inflammatory drugs (NSAIDs), and opiates are used for inflammatory pain and chronic pain respectively. ${ }^{13,14}$ Antidepressants that block monoamine uptake (amitriptyline, duloxetine, venlafaxine) anticonvulsants acting through a block of sodium channels (lidocaine, carbamazepine) or alteration of calcium channel function (e.g. ziconotide, gabapentin) or through increasing extracellular levels of the inhibitory transmitter gamma aminobutyric acid (GABA) (tigabine) and, to a lesser extent, opioids are used for neuropathic pain. Lidocaine, capsaicin can be used topically for patients with cutaneous allodynia and hyperalgesia. Mostly, drugs are used in combination with different targets and side effects for neuropathic pain. ${ }^{15}$

Generally neurotransmitters are involved in the work of regulation of central nervous system (CNS) activity. GABA A receptors are located post-synaptically and they mediate postsynaptic inhibition by increasing the $\mathrm{Cl}$ permeability and hyperpolarizing the cell. GABAA receptors are target for the several important centrally acting drugs like benzodiazepines, barbiturates. ${ }^{16}$ Similarly the tuber of the Ayurvedic plant A. paeoniifolius were found to have CNS depressant activity in mice. Some previous studies showed the petroleum ether extract of Amorphophallus paeoniifolius have cytotoxic, gastrokinetic, central depression action and muscle relaxant activity. ${ }^{17,18}$ 
Standard drug diclofenac sodium act on cyclooxygenase pathway of prostaglandins synthesis. The plant may have the phytoconstituents which inhibit cyclooxygenase enzyme or act on central opioid receptors (and receptors). ${ }^{19}$ It may also be due to the benzodiazepine receptor agonistic activity which depress the pain receptors and may be responsible for analgesic activity. One previous study states the presence of flavonoids, alkaloids and steroids in the phytochemical screening of Amorphophallus paeoniifolius tubers which may be responsible for analgesic activity. ${ }^{20,21}$

\section{CONCLUSION}

It was also concluded that the extract show analgesic activity either centrally and peripherally. The plant may have the phytoconstituents which peripherally inhibit cyclooxygenase enzyme for producing analgesia or act on central opioid receptors (and receptors. Further research is needed to isolate and screening of the constituents for analgesic activity.

Funding: No funding sources Conflict of interest: None declared

Ethical approval: The study was approved by the Institutional Ethics Committee of Karpagam faculty of Medical Sciences and Research, Coimbatore, India

\section{REFERENCES}

1. Tripathi KD. Essentials of Medical Pharmacology. 8th Ed. Jaypee Brothers Medical Publishers (P) Ltd.; 2018:453.

2. Rang HP, Dale MM, Ritter JM, Moore PK. Pharmacology. 9th Ed. Elservier; 2019:246.

3. Hardman JG, Limbird LE, Molinoff PA. Analgesicantipyretic and anti-inflammatory agents and drugs employed in the treatment of gout., 9th Ed. The Pharmacological Basis of Therapeutics, McGraw-Hill, New York; 1996:617.

4. De S, Dey YN, Ghosh AK. Phytochemical investigation and chromatographic evaluation of the different extracts of tuber of Amorphaphallus paeoniifolius (Araceae). Int J Pharm Biol Res. 2010;1(5):150-7.

5. Dey YN, De SH, Ghosh AK. Evaluation of analgesic activity of methanolic extract of Amorphophallus paeoniifolius tuber by tail flick and acetic acid-induced writhing response method. Int $\mathrm{J}$ Pharm Biosci. 2010;1:662-8.

6. Jagadheesh K, Arumugam V, Elangovan N, Kumar PP. Evaluation of Anti-tumor and Antioxidant Activity of Amorphophallus paeoniifolius on DMBA Induced Mammary Carcinoma. Inter J Chemical Pharma Sci. 2010;1(2):40-50.

7. Madhurima P, Kuppast IJ, Mankani KL. A review on Amorphophallus paeoniifolius. Inter $\mathrm{J}$ Adv Sci Res Technol. 2012;2(2):99-111.
8. Hasani AS, Soljakova M, Jakupi MH, Ustalar-Ozgen SZ. Preemptive analgesic effect of diclofenac: experimental study in rats. Middle East $\mathrm{J}$ Anaesthesiol. 2011;21(3):355-60.

9. Paul S, Saha D. Analgesic activity of methanol extract of Plumbago Indica (L) by Acetic acid induced writhing method. Asian J Pharm. 2012;2(2):74-76.

10. Tjolsen A, Rosland JH, Berge OG, Hole K. The increasing temperature hot-plat test: an improved test of nociception in mice and rats. $\mathrm{J}$ Pharmacol Meth. 1991;25:241-50.

11. Okuse K. Pain signaling pathways: from cytokines to ion channels. Int J Biochem Cell Biol. 2007;39:490-6.

12. Kissin I. The development of new analgesics over the past 50 years: a lack of real breakthrough drugs. Anest Analg. 2010;110:780-9.

13. Atkinson TJ, Fudin J, Jahn HL, Kubotera N, Rennick AL, Rhorer M. What's new in NSAID pharmacotherapy: oral agents to injectables. Pain Med. 2013;14(1):S11-7.

14. Yaksh T, Wallace MS. Opioids, analgesia, and pain management. Goodman and Gilman's The Pharmacological Basis of Therapeutics. Edited by Brunton L, Chabner B, Knollman B, New York: McGraw-Hill Medical. 2011;481-526.

15. Finnerup NB, Sindrup SH, Jensen TS. The evidence for pharmacological treatment of neuropathic pain. Pain. 2010;150:573-81.

16. Das SS, Sen M, Dey YN, De S, Ghosh AK. Effects of petroleum ether extract of Amorphophallus paeoniifolius tuber on central nervous system in mice. Indian J Pharm Sci. 2009;71:651-5.

17. Angayarkanni J, Ramkumar KM, Poornima T, Priyadarshini U. Cytotoxic activity of Amorphophallus paeniifolius tuber extracts in vitro. American-Euresian J Agric Environ Sci. 2007;2(4):395-8.

18. Dey YN, Mahor S, Kumar D, Wanjari M, Gaidhani S, Jadhav A. Gastrokinetic activity of Amorphophallus paeoniifolius tuber in rats. J Intercul Ethnopharmacol. 2016 Jan;5(1):36.

19. Dey YN, Ghosh AK. Pharmacognostic evaluation and phytochemical analysis of the tuber of Amorphophallus paeoniifolius. Int J Pharm Res Dev. 2010;2:44-9.

20. Sharstry RA, Biradar SM, Mahadevan KM, Habbu PV. Isolation and characterization of Secondary Metabolite from Amorphophallus paeoniifolius for Hepatoprotective activity. Res J Pharm Biol Chem Sci. 2010;1:429-37.

21. Nataraj HN, Murthy RLN, Setty SR. Pharmacognostical parameters for evaluation of leaves of Amorphophallus paeoniifolius. J Pharm Res. 2009;2:1370-2.

Cite this article as: Hemalatha A, Vinotha SAT. Analgesic activity of aqueous extract of Amorphophallus paeoniifolius in Swiss albino mice. Int J Basic Clin Pharmacol 2019;8:1327-30. 